\title{
Paper
}

\section{Dependence of Antibacterial Activity of ZnO Powders on Their Physico-chemical Properties}

\author{
Thi Minh Phuong NGUYEN ${ }^{1}$, Ken HIROTA ${ }^{1 *}$, Masaki KATO ${ }^{1}$, Kazuhiko TSUKAGOSHI ${ }^{1}$, \\ Hirohisa YAMADA ${ }^{2}$, Atsuki TERABE ${ }^{3}$ and Hideto MIZUTANI ${ }^{3}$ \\ ${ }^{1}$ Department of Molecular Chemistry \& Biochemistry, Faculty of Science \& Engineering, Doshisha University, \\ Tatara-miyako tani 1-3, Kyo-tanabe, Kyoto 610-0321, Japan. \\ ${ }^{2}$ Department of Chemical Engineering, National Institute of Technology, Nara College, Yata-cho 22, Yamatokoriyama, Nara 639-1080, Japan. \\ ${ }^{3}$ Sakai Chemical Industry Co., LTD, Ebisujima-cho 5-1, Sakai-ku, Sakai 590-0985, Japan.
}

Received April 5, 2019; Revised May 17, 2019; Accepted May 28, 2019

\begin{abstract}
Recently, bio-safe germicidal $\mathrm{ZnO}$ has been attracting much attention because of the interaction with various biomolecules chemically as well as physically. As its antibacterial activity is related to reactive oxygen species (ROS), the ROS have been investigated in terms of luminol chemiluminescence (CL) emitted from the $\mathrm{ZnO}$ surface. In this study, the relationship between the disinfect activity of four kinds of $\mathrm{ZnO}$ powders and their physico-chemical properties has been studied using XRD (X-Ray Diffraction), SEM (Scanning Electron Microscope), BET (Brunauer-Emmett-Teller), CL, ESR (Electron Spin Resonance), and XPS (X-ray Photoelectron Spectroscopy) and bio-test using E. coli. Four $\mathrm{ZnO}$ powders tested were as following; No. 1 is newly developed $\mathrm{ZnO}$, prepared via hydrothermal treatment in aqueous $\mathrm{Zn}\left(\mathrm{NO}_{3}\right)_{2}$ solution and then re-oxidized, which reveal a strong antimicrobial activity under dark conditions; No. 2 starting material for No. 1, derived from zinc acetate; No. 3 fine $\mathrm{ZnO}$ prepared at low-temperature heating of basic zinc carbonate; No. 4 conventional fine $\mathrm{ZnO}$ synthesized from vaporized metal $\mathrm{Zn}$ in air. All powders revealed antimicrobial activity in the dark; different amounts and kinds of ROS have been emitted from each $\mathrm{ZnO}$ powder, however, it has been cleared that its sustainability depends significantly on the contents of interstitial $\mathrm{Zn}$ contained in $\mathrm{ZnO}$ particles.
\end{abstract}

\section{KEY WORDS}

zinc oxide, antibacterial activity, reactive oxygen species, physico-chemical properties

\section{Introduction}

In the present age of advanced technologies, scientist and engineers are still making vast research about recurrence of infectious disease and bacterial contamination in all kinds of materials ${ }^{1)}$. Nowadays, a number of inorganic anti-bacterial agents have been attracting much attention from food- and medical-related manufacturers due to their high credibility in comparison with organic anti-bacterial agents. Currently, new nanostructured materials with bactericidal properties are being used for preventing microbial growth because of the physico-chemical properties, such as size, structure and surface of materials can enhance the antimicrobial activity ${ }^{2}$.

Metallic oxide powders, such as $\mathrm{TiO}_{2}$, especially Anatasetype $\mathrm{TiO}_{2}{ }^{3,4)}$, and $M \mathrm{O}^{1,5)}, M \mathrm{O}_{2}{ }^{1,4)}$ (here, $M$ : metal element) have been found to inhibit bacterial growth. On the other hand, zinc oxide $\mathrm{ZnO}$ has been reported by the present authors ${ }^{6-8)}$ to reveal sustainable antibacterial activity even under dark conditions by submitting reactive oxygen species (ROS). The generation of ROS

* Corresponding author, E-mail: khirota@mail.doshisha.ac.jp such as hydrogen peroxide $\left(\mathrm{H}_{2} \mathrm{O}_{2}\right)$, hydroxyl radicals $(\mathrm{OH} \cdot)$ and superoxide $\left(\mathrm{O}_{2}{ }^{-}\right)$from the surface of $\mathrm{ZnO}$ is the main origin of its sterilizing property; and their generation mechanism in the dark has been proposed ${ }^{6,79}$. Furthermore, the germ's damage caused by bactericidal inorganic substance such as $\mathrm{MgO}, \mathrm{CaO}$ and $\mathrm{ZnO}$, also has been explained by the changes in sensitivities of root cells ${ }^{8)}$.

For the better use of $\mathrm{ZnO}$ and in order to assist the expansion of powerful but non-toxic antimicrobial derivatives, there is much need for understanding the action process of $\mathrm{ZnO}$ nanoparticles against bacteria

In the recent findings, the essential process of the antibacterial effect is not coherent ${ }^{10,11)}$. However, a few studies have shown that the basic cause of the antibacterial function might be originated from the disruption of cell membrane activity ${ }^{12,13)}$. Another possibility could be the orientation of intercellular ROS, including hydrogen peroxide $\left(\mathrm{H}_{2} \mathrm{O}_{2}\right)$ which is a strong oxidizing agent harmful to bacterial cells ${ }^{6,13)}$. It has also been stated that $\mathrm{ZnO}$ can be initiated by UV and visible light to generate vastly ROS such

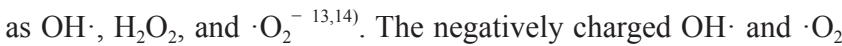


cannot penetrate into bacterial cells ${ }^{15}$.

The purpose of this study is to find the relationship between the physico-chemical properties and the antimicrobial activity of 4 kinds of $\mathrm{ZnO}$ powders described as follows; No. 1 the antibacterial $\mathrm{ZnO}$ which the authors have developed and reveals sustainable microbial activity in the dark ${ }^{6}$; No. 2 a commercially available $\mathrm{ZnO}$ powder (company product's name of "XZ-100F") which is the starting material for No. 1; No. 3 very fine $\mathrm{ZnO}$ powder ("FINEX-30") and No. 4 the conventional fine $\mathrm{ZnO}$ powder. These powders were prepared in much different methods and conditions. The synthesis ways might strongly affect on their physico-chemical properties. In the present study we have concentrated on both identifications of ROS submitted from the surface of each powder and what kind of ROS has strong influence on the disinfect activity of $\mathrm{ZnO}$ powders. From this study the antimicrobial activities of $\mathrm{ZnO}$ might be improved furthermore by understanding the nature of inhibitory and lethal effect of $\mathrm{ZnO}$ nanoparticles on bacteria.

\section{Experimental procedure}

\section{1 $\mathrm{ZnO}$ powder preparation}

In this study, 4 kinds of $\mathrm{ZnO}$ powders were used as listed in Table 1.

No. 1 sample is "antibacterial $\mathrm{ZnO}$ " powder, which was prepared by hydrothermal treatment in $\mathrm{Zn}\left(\mathrm{NO}_{3}\right)_{2} 3 \mathrm{M}$ aqueous solution at $443 \mathrm{~K}$ for $2.52 \times 10^{4} \mathrm{~s}$ and then re-oxidized at $773 \mathrm{~K}$ for $3.6 \times 10^{3} \mathrm{~s}$ in air and ball-milling ${ }^{7,16)}$, using commercially available fine $\mathrm{ZnO}$ ("XZ-100F", Sakai Chemical Industry Co., Ltd, Sakai, Osaka, Japan) with BET surface area $S_{\mathrm{A}}$ of $7.83 \mathrm{~m}^{2} \cdot \mathrm{g}^{-1}$, particle size $P_{\mathrm{s}}$ of $0.137 \mu \mathrm{m}$ determined using $S_{\mathrm{A}}$ and its theoretical density $\mathrm{D}_{\mathrm{x}}$ of $5.61 \mathrm{Mg} \cdot \mathrm{m}^{-3}$, as the same manner as our previous paper ${ }^{7}$. No. 2 sample is "XZ-100F" $\mathrm{ZnO}$ powder, which is a starting material used for No. 1 mentioned above. This sample was prepared from zinc acetate. No. 3 commercially available "FINEX-30" ZnO, (Sakai Chemical Industry Co., Ltd.) was synthesized by heating zinc carbonate at high temperature (673-1073 K) which is known as mechanochemical process ${ }^{17)}$. No. 4 sample is also conventional fine $\mathrm{ZnO}$ powder, which prepared by melting metallic zinc as "French method" $" 17)$ at $1173 \mathrm{~K}$, then cooling down to form zinc oxide as solid powder. All three ZnO No. 2-4 are commercial products.

\subsection{Evaluation}

X-ray diffraction (XRD, Ultima III, Smartlab, Rigaku, Tokyo, Japan) analysis using $\mathrm{Cu} K \alpha$ radiation (wavelength of $0.15418 \mathrm{~nm}$ ) with a graphite monochromator was utilized for determination of the crystalline phases and lattice parameters. Microstructural observation with field emission-type scanning electron microscopes (FE-SEM, JSM-7001FD, JSM-7800, JEOL Ltd., Tokyo, Japan) was performed on the $\mathrm{ZnO}$ powders prepared under various conditions. BET surface areas $S_{\mathrm{a}}$ of powders were measured using a particle characterization analyzer (Tristar II, Micromeritics Japan, Tokyo) at room temperature. Chemiluminescence (CL) ${ }^{6,7,16)}$ of $\mathrm{ZnO}$ powders $(100 \mu \mathrm{mol})$ in a $0.25 \mathrm{~mL}\left(2.5 \times 10^{-7} \mathrm{~m}^{3}\right)$ aqueous luminol solution $\left(5.0 \mu \mathrm{mol} / \mathrm{L}, 5.0 \times 10^{-9} \mathrm{~mol} \cdot \mathrm{m}^{-3}\right)$ mixed with $3.0 \mathrm{~mL}(3.0 \times$ $\left.10^{-6} \mathrm{~m}^{3}\right)$ carbonic acid buffer solution $\left(\mathrm{NaOH} / \mathrm{NaHCO}_{3}, \mathrm{pH}=10.8\right)$ was observed in the dark condition using a CL detector (CLD100FC, Tohoku Electronic Industrial Co., Ltd., Sendai, Japan $)^{6}$. After dropping the luminol solution in a $1.2 \times 10^{2} \mathrm{~s}$ 'warming up of the detector, the intensity of CL was integrated between 1.2 6.0 $\times$ $10^{2} \mathrm{~s}$. In the order to determine interstitial $\mathrm{Zn}$ contained in crystalline structure of $\mathrm{ZnO}$, i.e., $\mathrm{Zn}_{1+\delta} \mathrm{O}$, the following procedure was performed. (I) The weight of $\mathrm{ZnO}$ powder $M_{\mathrm{ZnO}}$ after heating at $573 \mathrm{~K}$ for $6.0 \times 10^{2} \mathrm{~s}$ in air was measured using a precision electric balance (here, this temperature and time was determined in terms of complete elimination of water adsorbed on the surface of $\mathrm{ZnO}$ using the DTA/TG). (II) The mass of oxygen content $M_{\mathrm{O}}$ of the same $\mathrm{ZnO}$ powder sample was measured using an OxygenNitrogen Analyzer ("EMGA620W", Horiba Scientific, Kyoto, Japan) 5 times. The average value of $M_{\mathrm{O}}$ was determined. (III) From this $M_{\mathrm{O}}$ value, the oxygen mole $n_{\mathrm{O}}$ was calculated. Then the mol of $\mathrm{Zn}, n_{\mathrm{Zn}}$, in the same sample was estimated from the following equation: $n_{\mathrm{Zn}}=\left[M_{\mathrm{ZnO}}-16.00 \times n_{\mathrm{O}}\right] / 65.41$; here, 16.00 and 65.41 are atomic weights of oxygen and zinc, respectively. The content of interstitial $\mathrm{Zn}, \delta$, was determined by an equation of $n_{\mathrm{Zn}} / n_{\mathrm{O}}=1+\delta$. As photoluminescence (PL) analysis is ideally suited for compositional analysis of defect evaluation of lightemitting materials ${ }^{18)}$. PL measurement (Fluorolog ${ }^{\circledR}-3,450 \mathrm{~W}$

Table 1 Preparation conditions for 4 kinds of $\mathrm{ZnO}$ powders

\begin{tabular}{|c|c|c|c|c|}
\hline Sample & Precursors & Preparation method & Synthesis conditions & Properties \\
\hline $\begin{array}{c}\text { No 1 } \\
\text { Antibacterial } \\
\text { ZnO }\end{array}$ & $\begin{array}{c}\mathrm{XZ}-100 \mathrm{~F} \mathrm{ZnO} \\
3 \mathrm{M} \mathrm{Zn}\left(\mathrm{NO}_{3}\right)_{2} \text { aq. }\end{array}$ & $\begin{array}{c}\text { Hydrothermal } \\
\text { treatment } \\
\text { Ball milling }\end{array}$ & $\begin{array}{l}\text { Reaction temp.: } 443 \mathrm{~K}, 2.52 \times 10^{4} \mathrm{~s} \\
\text { Drying: overnight, } 353 \mathrm{~K} \\
\text { Calcinaion } 773 \mathrm{~K}, 3.6 \times 10^{3} \mathrm{~s} \text { in air } \\
\text { Ball-milling: } 2 \mathrm{~mm}^{\phi} \mathrm{YTZ}, 3.6 \times 10^{3} \mathrm{~s}\end{array}$ & $\begin{array}{l}\text { Hexagonal } \\
\text { Wurtzite } \\
\text { structure } \\
2.69 \mathrm{~m}^{2} / \mathrm{g}\end{array}$ \\
\hline $\begin{array}{c}\text { No } 2 \\
\text { XZ-100F }\end{array}$ & $\mathrm{Zn}\left(\mathrm{CH}_{3} \mathrm{COO}\right)_{2}$ & - & - & $\begin{array}{l}\text { Wurtzite } \\
7.83 \mathrm{~m}^{2} / \mathrm{g}\end{array}$ \\
\hline $\begin{array}{c}\text { No } 3 \\
\text { FINEX-30 }\end{array}$ & $\mathrm{ZnCO}_{3}$ & $\begin{array}{l}\text { Mechanochemical } \\
\text { process }\end{array}$ & $\begin{array}{l}\text { Calcination temp.: } \\
\quad 673-1073 \mathrm{~K}\end{array}$ & $\begin{array}{l}\text { Wurtzite } \\
27.4 \mathrm{~m}^{2} / \mathrm{g}\end{array}$ \\
\hline $\begin{array}{c}\text { No } 4 \\
\text { Conventional } \\
\text { Fine ZnO }\end{array}$ & Metallic Zinc & $\begin{array}{l}\text { French method } \\
\text { (indirect process) }\end{array}$ & $\begin{array}{l}\text { Melting temp.: } 1173 \mathrm{~K} \\
\text { Cooling ZnO particles }\end{array}$ & $\begin{array}{l}\text { Wurtzite } \\
9.06 \mathrm{~m}^{2} / \mathrm{g}\end{array}$ \\
\hline
\end{tabular}


Xe short arc lamp, Xe flush lamp with double monochromator, HORIBA, Kyoto, Japan) was applied to identify interstitial zinc in the crystalline structure of $\mathrm{ZnO}$ powders at room temperature. X-ray Photoelectron Spectroscopy XPS or Electron Spectroscopy for Chemical Analysis, ESCA) analysis (ESCA3057, ULVACPHI. Inc., Chigasaki, Kanagawa, Japan) was utilized to analyze the surface chemical state of 4 kinds $\mathrm{ZnO}$. A monochromated $\mathrm{A} 1 \mathrm{K \alpha} \mathrm{X}$-ray source $(1486.6 \mathrm{eV})$ was used and operated at $150 \mathrm{~W}$ in a pressure of $1.333 \times 10^{-12} \mathrm{~Pa}$. All the binding energies were referenced to the $\mathrm{Au}_{4 \mathrm{f} / 2}$ peak located at $84.2 \mathrm{eV}$ attributed to the surface sputtered-Au. Chemiluminescence (CL) with scavengers such as, 2-5 dimethyl furan (singlet oxygen, ${ }^{1} \mathrm{O}_{2}$, Wako Ltd., Tokyo, Japan), nitro blue tetrazolium (superoxide, $\cdot \mathrm{O}_{2}^{-}$, Nacalai tesque, INC., Kyoto, Japan), 2-propanol (hydroxyl radical, OH·, Nacalai tesque, INC., Kyoto, Japan), and riboflavin (hydrogen per oxide, $\mathrm{H}_{2} \mathrm{O}_{2}$, Wako Ltd.) measurements were utilized at room temperature in the dark to identify the reactive oxygen species (ROS) of $\mathrm{ZnO}$ powders ${ }^{6}$. Antibacterial test for various kinds of $\mathrm{ZnO}$ powders was evaluated with a colony count method using $E$. coli bacteria on nutrient agar medium in a Na-P buffer solution. The penetrated culture of bacteria was kept at $309 \mathrm{~K}$ for $8.64 \times$ $10^{4} \mathrm{~s}$ in a laboratory incubator. $\mathrm{ZnO}$ powders were added to a small amount of bacteria and mixed with $10 \mathrm{~mL} \mathrm{Na-P}$ buffer solution in the sunshade.

\section{Results and discussions}

\subsection{Characteristics of $\mathrm{ZnO}$ powders}

Fig. 1 shows XRD patterns of 4 kinds of $\mathrm{ZnO}$ powders; all samples have hexagonal Würzite structure. There is not so much

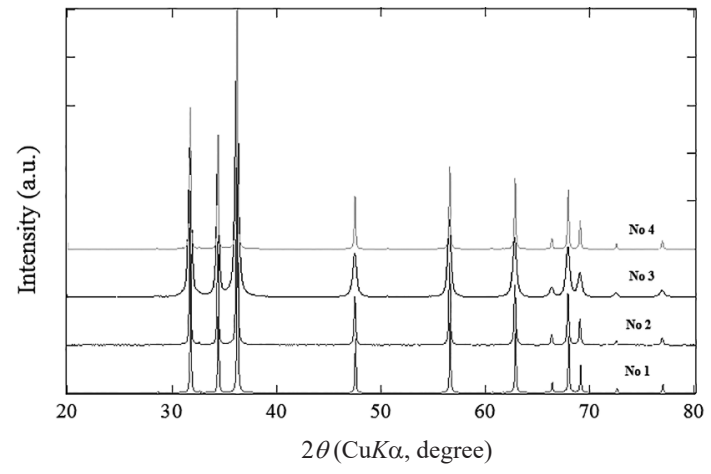

Fig. 1 XRD patterns of 4 kinds of $\mathrm{ZnO}$. significant difference in their lattice parameters among them (Table 2). As No. 1 powder was prepared from No. $2 \mathrm{ZnO}$ by hydrothermal treatment, the lattice parameters of No. 1 are a little larger than those of No. 2. However, $a$ and $c$ of No. $2 \mathrm{ZnO}$ are a little smaller than the rest, its unit volume is the smallest among them. Crystallite size of No. 3 is the smallest due to its preparation method in which zinc carbonate was calcined at high temperatures, suggesting the finest powder among them. SEM photographs shown in Fig. 2 display the morphology and particle sizes of $\mathrm{ZnO}$ powders. ZnO particle's shapes are sphere and some of them are hexagonal column. Besides, the particle size, $P_{\mathrm{s}}$, of 4 samples that evaluated based on BET surface area values as indicated below the photographs are consistent with the SEM observation, predicting that the differences in their morphologies and particle sizes might affect to their antibacterial properties. Fig. 3 shows the integrated chemiluminescence intensity, $\sum \mathrm{CL}$, accumulated for $4.8 \times 10^{2} \mathrm{~s}$ under dark conditions as the blue bar graphs. Obviously, the CL value of No. 3 FINEX 30 fine powder is much higher than the other $\mathrm{ZnO}$ powders. With $\mathrm{CL}$ results, No. $3 \mathrm{ZnO}$ powder is expected to reveal strong activity on bacteria. As it is clear that the surface area has much effect on the value of $\sum \mathrm{CL}$, the $\sum \mathrm{CL}$ values per unit area, $\sum \mathrm{CL} / S_{\mathrm{A}}$, were calculated and shown in red bar graphs in Fig. 3. By comparing these $\sum \mathrm{CL} / S_{\mathrm{A}}$ values, there is little difference from No. 2 to No. 4; dare to say, No. 1 reveals a little smaller value.

$\mathrm{ZnO}$ is non-stoichiometric chemical compound with the chemical formula $\mathrm{Zn}_{1+\delta} \mathrm{O}$. After various treatments, for example, hydrothermal treatment and following re-oxidation, interstitial zinc ions in the $\mathrm{ZnO}$ lattice can be formed. These zinc interstitials are the main source of generation of $\operatorname{ROS}^{19}$. Fig. 4 displays the values in the formula $\mathrm{Zn}_{1+\delta} \mathrm{O}$ of 4 kind $\mathrm{ZnO}$ powders. These values were determined from the oxygen content of $\mathrm{ZnO}$ powders as explained in experimental procedure. As $\delta$ value reflects the amount of interstitial zinc, this value also affects to the amount of ROS those could be generated from the surface of $\mathrm{ZnO}$ powder ${ }^{6,7)}$. No 1 sample gave the highest $\delta$, on the contrary, No. 3 did the lowest $\delta$, even though high CL. From here it is expected to submit high amount of ROS from the surface of No. $1 \mathrm{ZnO}$ and resulted in the sustainable microbial activity under dark conditions ${ }^{6}$. Fig. 5 shows the photoluminescence spectra (PL) of 4 samples. As all the measured data on Fluorolog3 equipped with a xenon lamp were re-calculated for optical filter transparency correction, some

Table 2 Lattice parameters and crystallite size of $\mathrm{ZnO}$ powders.

\begin{tabular}{|c|c|c|c|c|c|c|c|}
\hline \multirow{2}{*}{ Sample } & \multicolumn{3}{|c|}{ Lattice parameters } & \multirow{2}{*}{$\begin{array}{c}d(100) \\
(\mathrm{nm})\end{array}$} & \multirow{2}{*}{$\begin{array}{c}d(001) \\
(\mathrm{nm})\end{array}$} & \multirow{2}{*}{$\begin{array}{c}d(101) \\
(\mathrm{nm})\end{array}$} & \multirow{2}{*}{$\begin{array}{l}\text { Crystallite } \\
\text { size (nm) }\end{array}$} \\
\hline & $a(\mathrm{~nm})$ & $c(\mathrm{~nm})$ & $v\left(\mathrm{~nm}^{3}\right)$ & & & & \\
\hline No 1 & 0.32490 & 0.52055 & 0.04869 & 0.009606 & 0.011853 & 0.007344 & 60.8 \\
\hline No 2 & 0.32468 & 0.52024 & 0.04860 & 0.0144575 & 0.0165865 & 0.013617 & 43.3 \\
\hline No 3 & 0.32484 & 0.52069 & 0.04868 & 0.01929 & 0.023483 & 0.020675 & 23.1 \\
\hline No 4 & 0.32489 & 0.52052 & 0.04868 & 0.00973 & 0.011161 & 0.00759 & 45 \\
\hline
\end{tabular}



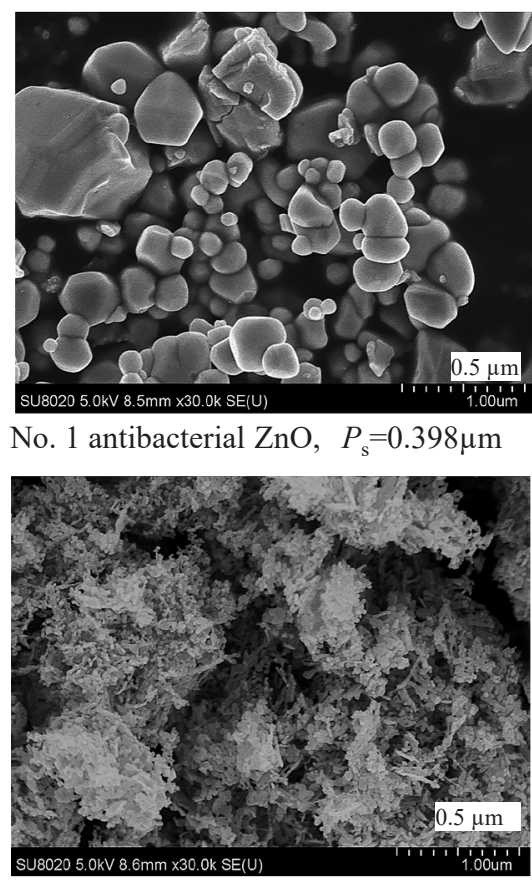

No. 3 FineX-30, $P_{\mathrm{s}}=0.039 \mu \mathrm{m}$

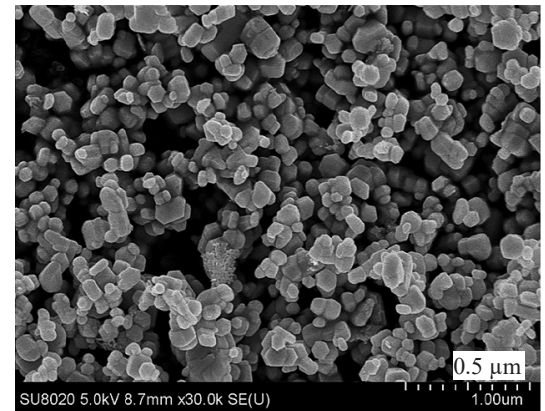

No. 2 XZ-100F ZnO, $P_{\mathrm{s}}=0.149 \mu \mathrm{m}$

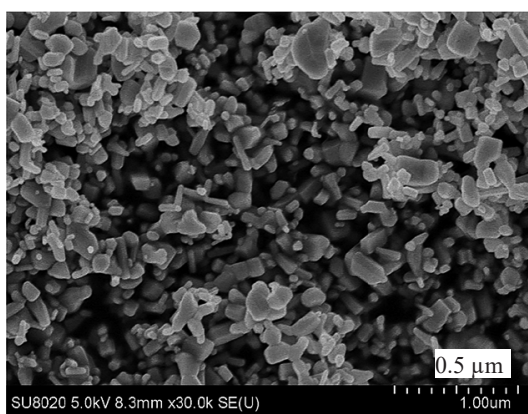

No. 4 Conventional $\mathrm{ZnO}$ powder, $P_{\mathrm{s}}=0.118 \mu \mathrm{m}$

Fig. 2 SEM images of 4 kinds of $\mathrm{ZnO}$ powders.

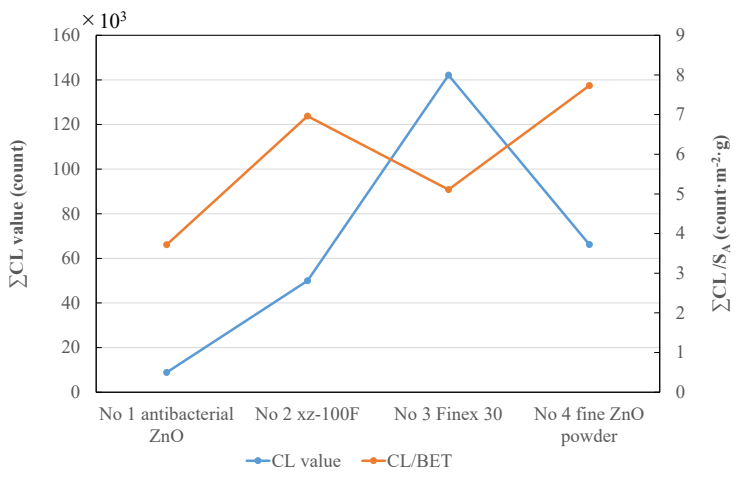

Fig. $3 \Sigma \mathrm{CL}$ and $\Sigma \mathrm{CL} / S_{\mathrm{A}}\left[S_{\mathrm{A}}\right.$ : BET surface area $\left.\left(\mathrm{m}^{2} / \mathrm{g}\right)\right]$ of 4 kinds of $\mathrm{ZnO}$ powders.

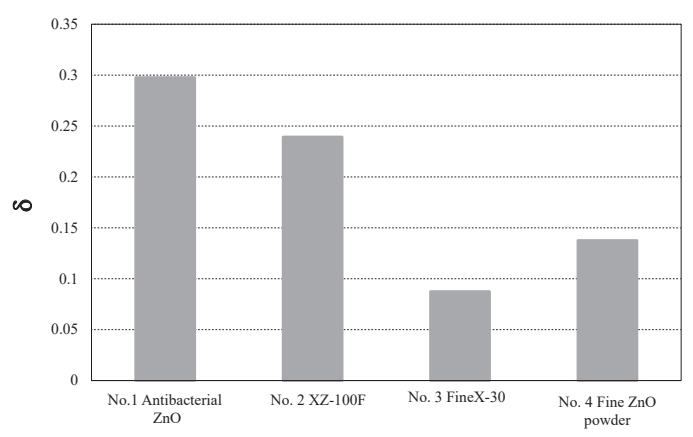

Fig. $4 \delta$ values for interstitial $\mathrm{Zn}_{\mathrm{i}}$ in $\mathrm{ZnO}$ powders.

data have obvious intensity gap between the shorter wavelength range and longer wavelength range. These emission spectra that include the intensity gap should not be connected enforcedly using artificial normalization in order to avoid forgery, because these gaps originate from the photobreaching, which is one of well-

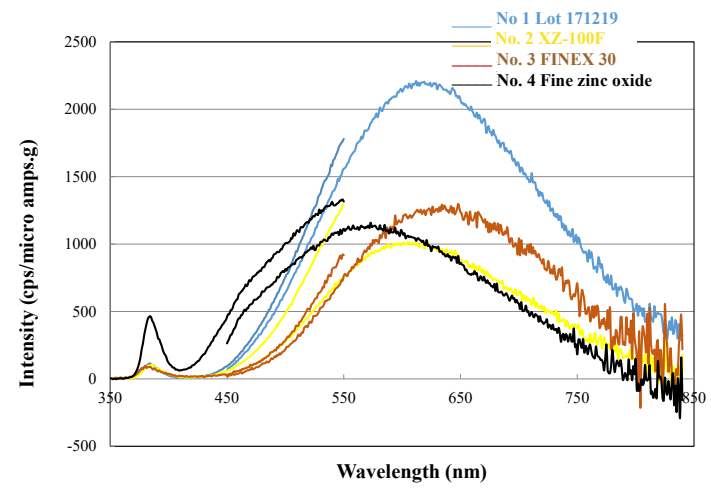

Fig. 5 PL spectra of 4 kinds $\mathrm{ZnO}$ powders.

known fluorescence feature ${ }^{20)}$. Basing on some previous studies ${ }^{21)}$, the peak around $600 \mathrm{~nm}$ wavelength corresponds to interstitial zinc and the intensity of PL peak is related to the amount of interstitial zinc. From these spectra, it is easy to notice that the peak at $625 \mathrm{~nm}$ of No. 1 sample shows the highest intensity. Therefore, the PL data also support that this sample includes the high amount of interstitial zinc, consisting with high $\delta$ value of No. $1 \mathrm{ZnO}$ sample. XPS analysis as shown in Fig. 6 was utilized to understand the surface chemical state of 4 kinds $\mathrm{ZnO}$. Oxygen vacancy Vö peak is clearly observed in No. 1 antibacterial $\mathrm{ZnO}$ sample. Moreover, $\mathrm{Zn} 2 p_{3 / 2}$ peak of No. 1 sample shifted to higher binding energy of $0.2 \mathrm{eV}$. This peak shift would be caused by electron density of $\mathrm{Zn}^{2+}$ core level affected by Vö. Therefore, No. 1 antibacterial sample has many active site/surface areas. The surface Vö ratio of No. 3 sample is the almost same intensity as the other non-treated samples. However, the surface area of No. 3 is much higher than 


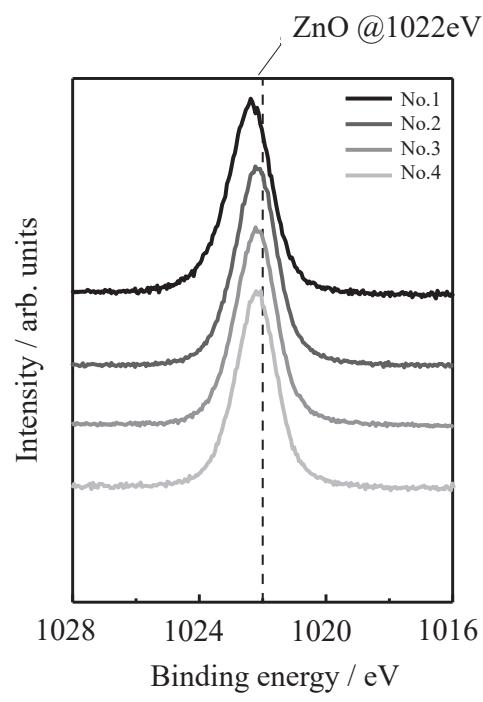

Peak corrected by sputtered Au4f7/2@84.2 eV Turner N.H., Single A.M., Surf. Interface Anal. 15, 215 (1990)

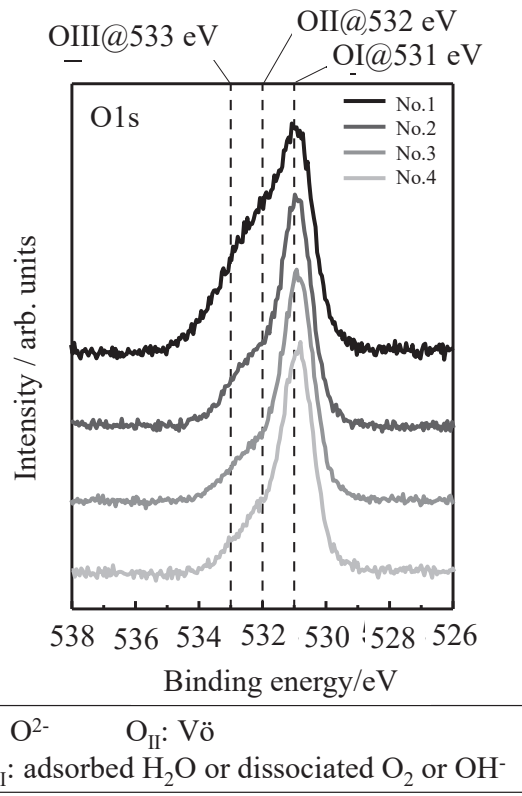

Fig. 6 XPS spectra of $\mathrm{Zn} 2 p^{3 / 2}$ peak and oxygen $1 s$ peak.

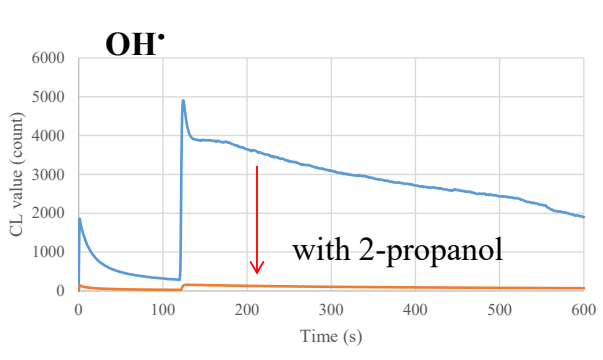

—Without 2-propanol —With 2-propanol

$\mathrm{H}_{2} \mathrm{O}_{2}$

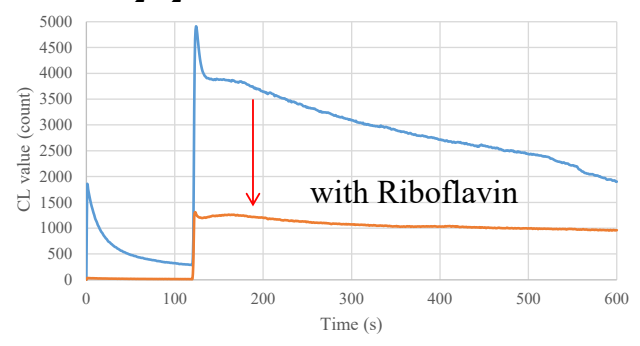

—Without Riboflavin —With Riboflavin

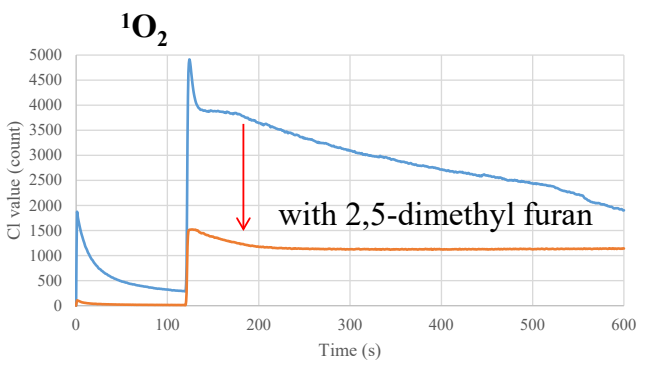

- Without 2,5 dimethylfuran —with 2,5-dimethylfuran

$\cdot \mathrm{O}_{2}^{-}$

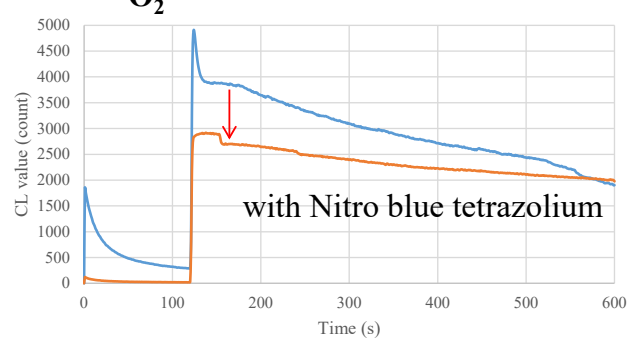

—without Nitro blue _— With Nitroblue

Fig. 7 CL with scavenger for No. $1 \mathrm{ZnO}$ powder.

other samples, so the total active-site number is many more than those of other non-treatment samples. The antibacterial effect of No. 3 might be due mainly to its high surface area.

\section{$3.2 \mathrm{ROS}$ from the $\mathrm{ZnO}$ surface}

The determination of which kind of radical oxygen species ROS generated from the $\mathrm{ZnO}$ surface was conducted using various methods. At first, CL-scavenger method was applied; in this method, a specific scavenger that can trap the corresponding ROS. In Fig. 7, the blue and red curves are CL ones before and after scavenger-addition, respectively. For example, in No. 1 as the representative sample, the CL intensity is strongly decreased after addition of scavenger such as 2-propanol, 2,5-dimethyl furan, riboflavin, and nitro blue tetrazolium; they can trap hydroxyl radical $\mathrm{OH} \cdot$, singlet oxygen ${ }^{1} \mathrm{O}_{2}$, hydrogen peroxide $\mathrm{H}_{2} \mathrm{O}_{2}$, and superoxide radical $\cdot \mathrm{O}_{2}{ }^{-}$, respectively. Therefore, it would be concluded that No. 1 sample could submit all 4 kinds of ROS such as $\mathrm{OH} \cdot{ }^{1} \mathrm{O}_{2}, \mathrm{H}_{2} \mathrm{O}_{2}$ and $\cdot \mathrm{O}_{2}{ }^{-}$. Fig. 8 represents that the combination of CL-scavenger curves for No. 2, 3 and $4 \mathrm{ZnO}$ powders. Each powder only submits one kind of ROS; No. $2{ }^{1} \mathrm{O}_{2}$, No. $3 \mathrm{H}_{2} \mathrm{O}_{2}$ and No. $4 \mathrm{OH} \cdot$. To confirm the results obtained from CL-scavenger method, another testing method, which we call, bio-test with scavenger was utilized. The principle of this method is near the 

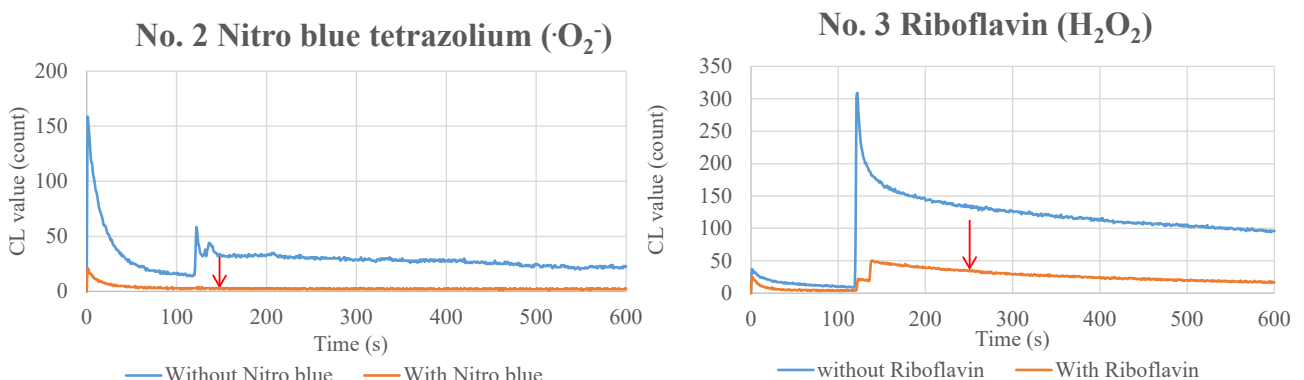

—Without Nitro blue —With Nitro blue

—without Riboflavin —With Riboflavin

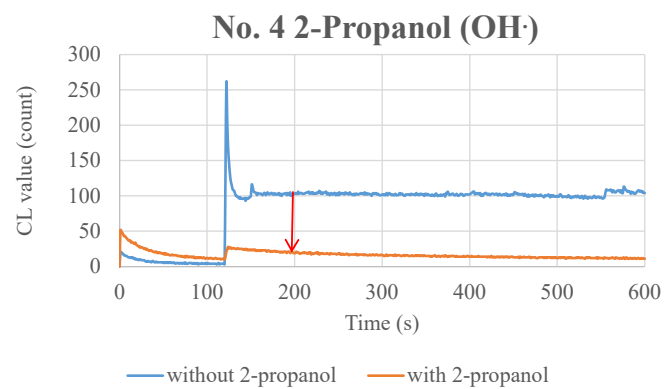

Fig. 8 CL with scavenger for No. 2 4 $\mathrm{ZnO}$ powders.
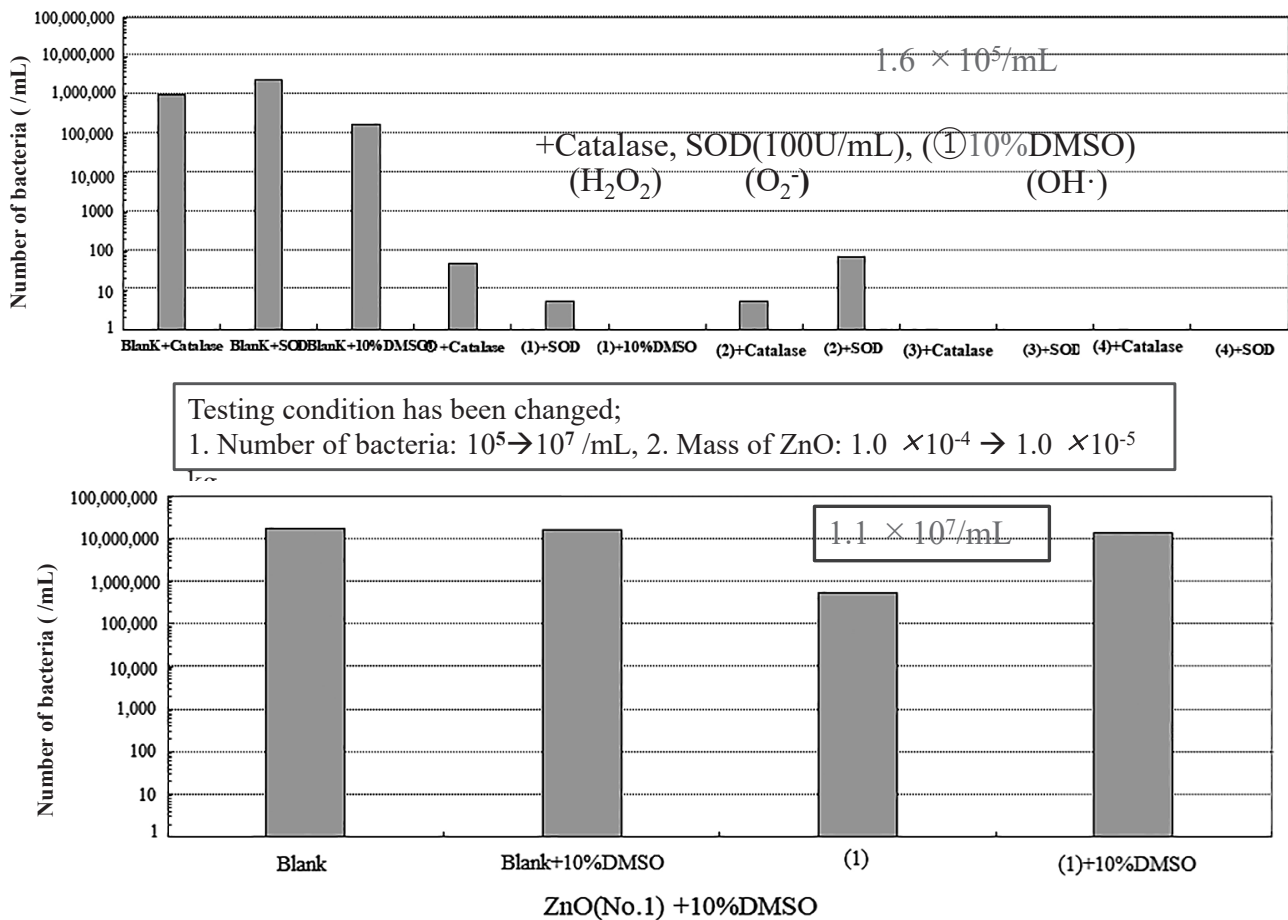

Fig. 9 Bio-test using scavengers under dark conditions.

same as CL-scavenger method, in other words, some specific scavengers (catalase $\left[\mathrm{H}_{2} \mathrm{O}_{2}\right]$, superoxide dismutase SOD $\left[\cdot \mathrm{O}_{2}{ }^{-}\right]$, $10 \%$ DMSO $\left[\mathrm{OH}^{\cdot}\right]$ ) which can catch the corresponding ROS to ZnO powders: (1), (2), (3) and (4) correspond to No. 1, No. 2, No. 3 and No. 4, respectively, in Fig. 9, were adopted. At first, $10 \%$ dimethyl sulfoxide DMSO which is a scavenger for $\mathrm{OH}$, was used for the first testing condition. As shown in Fig. 9, after $8.64 \times$ $10^{4} \mathrm{~s}$ testing on $E$. coli under dark conditions, all samples proved that they could kill all bacteria. These results are not consistent with the CL-scavenger results, so that the number of bacteria was increased from $10^{5}$ to $10^{7} / \mathrm{mL}$ and also the amount of $\mathrm{ZnO}$ powder was decreased from $1.0 \times 10^{-4}$ to $1.0 \times 10^{-5} \mathrm{~kg}$, the results are shown in Fig. 9. From this, it is easily noticed that both No. 1 and $2 \mathrm{ZnO}$ powders could submit ROS. From the results of CL and biotest with scavengers, Table 3 summarizes what kinds of ROS are emitted from each sample ( $\bigcirc$ : submission of ROS was confirmed by the above-mentioned measurement, $\times$ : no submission, - : submission process itself was not performed); No 1, as mentioned, submitted all ROS. No. 2 XZ-100F generates hydrogen peroxide $\left(\mathrm{H}_{2} \mathrm{O}_{2}\right)$ and superoxide radical $\left.{ }^{(} \cdot \mathrm{O}_{2}{ }^{-}\right)$. No. 3 two kinds of ROS i.e., 
Table 3 Summary of ROS submitted from 4 kinds of $\mathrm{ZnO}$ powders.

\begin{tabular}{|c|c|c|c|c|c|c|c|c|}
\hline \multirow[t]{2}{*}{ Sample } & \multicolumn{2}{|c|}{$\mathrm{OH} \cdot$} & \multicolumn{2}{|c|}{$\mathrm{H}_{2} \mathrm{O}_{2}$} & \multicolumn{2}{|c|}{${ }^{1} \mathrm{O}_{2}$} & \multicolumn{2}{|c|}{$\mathrm{O}_{2}^{-}$} \\
\hline & CL & $\begin{array}{l}\text { Bio-test } \\
\text { (DMSO) }\end{array}$ & CL & $\begin{array}{l}\text { Bio-test } \\
\text { (catalase) }\end{array}$ & CL & Bio-test & CL & $\begin{array}{l}\text { Bio-test } \\
\text { (SOD) }\end{array}$ \\
\hline $\begin{array}{l}\text { No. } 1 \\
\text { Antibacterial ZnO }\end{array}$ & $\circ$ & $\circ$ & $\circ$ & $\circ$ & $\circ$ & - & $\circ$ & 0 \\
\hline $\begin{array}{c}\text { No. } 2 \\
\text { XZ-100F }\end{array}$ & $x$ & - & $x$ & 0 & $x$ & - & $\circ$ & $\circ$ \\
\hline $\begin{array}{c}\text { No. } 3 \\
\text { FINEX } 30\end{array}$ & $\times$ & - & $\circ$ & $\circ$ & $x$ & - & $x$ & $\circ$ \\
\hline $\begin{array}{c}\text { No. } 4 \\
\text { Fine zinc oxide }\end{array}$ & $\circ$ & - & $\times$ & 0 & $x$ & - & $\times$ & $\circ$ \\
\hline
\end{tabular}

Table 4 MRSA bio-test results.

\begin{tabular}{|c|c|c|c|c|}
\hline \multirow{2}{*}{ Germ (Bacteria) } & \multirow{2}{*}{ Object (samples) } & \multirow{2}{*}{ Concentration } & \multicolumn{2}{|c|}{ Number of active germs $(/ \mathrm{mL})$} \\
\hline & & & before & after $8.64 \times 10^{4} \mathrm{~s}$ \\
\hline \multirow{5}{*}{ MRSA } & antibacterial $\mathrm{ZnO}$ & $1 \mathrm{mass} \%$ & - & $<10$ \\
\hline & $\mathrm{XZ}-100 \mathrm{~F}$ & 1 mass $\%$ & - & $<10$ \\
\hline & FINEX-30 & $1 \mathrm{mass} \%$ & - & $<10$ \\
\hline & Fine zinc oxide powder & $1 \mathrm{mass} \%$ & - & $<10$ \\
\hline & Reference & & $1.9 \times 10^{5}$ & $1.1 \times 10^{5}$ \\
\hline \multicolumn{5}{|c|}{ Reference: a physiological salt } \\
\hline \multicolumn{5}{|c|}{ Culture condition: $298 \mathrm{~K}$ in the shading } \\
\hline$<10$ : not detected & & & & \\
\hline
\end{tabular}

$\mathrm{H}_{2} \mathrm{O}_{2}$ and $\cdot \mathrm{O}_{2}^{-}$, and No. 4 three kinds of hydroxyl radical $(\mathrm{OH} \cdot)$, $\mathrm{H}_{2} \mathrm{O}_{2}$ and $\cdot \mathrm{O}_{2}^{-}$, respectively.

\subsection{MRSA (Methicilin-resitant Staphylococcus aureus) test}

Finally, MRSA which is very famous as resistant bacteria and harmful to patients in the hospitals, was bio-tested in Kobe Center of Japan Textile Products Quality and Technology Center; all 4 kinds $\mathrm{ZnO}$ powers revealed antibacterial activity on MRSA even under dark conditions, Table 4 shows the results of MRSA bio-test after $8.64 \times 10^{4} \mathrm{~s}$ at $309 \mathrm{~K}$, all $\mathrm{ZnO}$ powders killed almost $100 \%$ the amount of bacteria.

\section{Conclusions}

Although all $\mathrm{ZnO}$ powders revealed strong antibacterial activity under dark conditions, we found a new relationship between the antibacterial properties and physico-chemical properties from the results of the $\delta$ in nonstoichiometric compound $\mathrm{Zn}_{1+\delta} \mathrm{O}$ and photoluminescence (PL) spectra. As the $\delta$ indicates the content of $\mathrm{Zn}_{\mathrm{i}}$ in the $\mathrm{ZnO}$ lattice, and these $\mathrm{Zn}_{\mathrm{i}}$ have strong effect with submission of ROS, and high PL peak at $625 \mathrm{~nm}$ also reflects the content of $\mathrm{Zn}_{\mathrm{i}}$, therefore No. 1 antibacterial $\mathrm{ZnO}$ powder can produce much ROS continuously. From the application viewpoints, FINEX-30 or XZ-100F can be applicable for one and short time usage.

\section{Acknowledgment}

The authors express their appreciation to Mr. Yuichi Kitagawa of J HORIBA TECHNO SERVICE CO., LTD, Kyoto, Japan, for his technical assistance and advice in the PL measurement of $\mathrm{ZnO}$. The authors thank Ms. M. Toda and Ms. J. Morita of the Doshisha University Research Center for Interfacial Phenomena, for FESEM observations of the samples.

\section{References}

1) V. V. Kumar, S. P. Anthony: Surface Chemistry of Nanobiomaterials, 9 (2016) 265-300.

2) G. Applerot, A. Lipovsky, R. Dror, N. Perkas, Y. Nitzan, R. Lubart, A. Gedanken: Adv. Functional Mater., 19 (2009) 842-852.

3) L. K. Adams, D. Y. Lyon, P. J. J. Alvarez: Water Res., 40 (2006) 3527-3532.

4) C. Karunakaran, G. Abiramasundari, P. Gomathisankar, G. Manikandan, V. Anandi: Mater. Res. Bull., 46 (2011) 15861592.

5) J. Sawai: J. Microbiological Methods, 54 (2003) 177-182.

6) K. Hirota, M. Sugimoto, M. Kato, K. Tsukagoshi, T. Tanigawa, H. Sugimoto: Ceram. Inter., 36 (2010) 497-506.

7) T. M. P. Nguyen, S. Hirota, Y. Suzuki, M. Kato, K. Hirota, H. Taguchi, H. Yamada, K. Tsukagoshi: J. Jpn. Soc. Powder Powder Metall., 65 (2018) 316-324.

8) Y. W. Wang, A. Cao, Y. Jiang, X. Zhang, J. H. Liu, Y. Liu, H. Wang: App. Mater. \& Interfaces, 6 (2014) 2791-2798.

9) B. T. Zhang, L. X. Zhao, J. M. Lin: J. Environmental Sci., 20 (2008) 1006-1011.

10) L. Zhang, Y. Ding, M. Povey, D. York: Prog. Nat. Sci., 18 
(2008) 939-944.

11) E. Hoseinzadeha, M. Y. Alikhanib, M. R. Samarghandic, M. S. Sibonid: Desalination and Water Treatment, (2013) 1-8.

12) T. Jin, D. Sun, J. Y. Su, H. Zhang, H-J. Sue: J. Food Sci., 74 (2009) 46-52.

13) A. Sirelkhatim, S. Mahmud, A. Seeni, N. H. M. Kaus, L. C. Ann, S. K. M. Bakhori, H. Hasan, D. Mohamad: Nano-Micro Lett., 7 (2015) 219-242.

14) Z. Cheng, H. Zhou, J. Yin, L. Yu: Journal of Agricultural and Food Chem., 55 (2007) 3325-3333.

15) L. Wang, C. Hu, L. Shao: Inter. J. Nanomedicine, 12 (2017) 1227-1249.
16) L. Irimpan, V. P. N. Nampoori, P. Radhakrishnan, A. Deepthy, B. Krishnan: J. App. Phys., 102 (2007) 063524.

17) A. Kołodziejczak-Radzimska, T. Jesionowski: A Review, Mater., 7 (2014) 2833-2881.

18) J. Gupta, D. Bahadur: ACS Omega, 3 (2018) 2956-2965.

19) K. Vanheusden, W. L. Warren, C. H. Seager, D. R. Tallant, J. A. Voigt: J. App. Phys., 79 (1996) 7983-7990.

20) C. Eggeling, J. Widengren, R. Rigler, C. A. M. Seidel: Anal. Chem., 70 (1998) 2651-2659.

21) G. Singh, E. M. Joyce, J. Beddow, T. J. Mason: Biotechnology and Food Sci., 2 (2012) 106-120. 